ALMEIDA, SP; SOUZA, JMM; AMORIM, AMT; GUSMÃO, SAL; SOUZA, RORM; SANTOS, AS. 2020. In vitro culture of jambu with different growth regulators. Horticultura Brasileira 38: 134-138. DOI - http://doi.org/10.1590/S0102-053620200204

\title{
In vitro culture of jambu with different growth regulators
}

\author{
Susan P Almeida ${ }^{1} \mathbb{D}$; Joanne MM Souza ${ }^{1} \mathbb{D}$; Andredy MT Amorim ${ }^{1} \mathbb{D}$; Sérgio AL de Gusmão ${ }^{1 \mathbb{D}}$; Rodrigo \\ ORM Souza ${ }^{1} \mathbb{D} ;$ Alberdan S Santos ${ }^{2} \mathbb{D}$
}

${ }^{1}$ Universidade Federal Rural da Amazônia (UFRA), Belém-PA, Brasil; susanpinheirosp@gmail.com; joanne.souza@ufra.edu.br; andredymurilo@yahoo.com.br; sergio.gusmão@ufra.edu.br; rodrigo.souza@ufra.edu.br; ${ }^{2}$ Universidade Federal do Pará (UFPA), BelémPA, Brasil; alberdan@ufpa.br

\begin{abstract}
The aim of this study was to establish the best concentrations of growth regulators for in vitro cultivation of jambu for a subsequent elaboration of an efficient micropropagation protocol. After sterilized, the seeds were inoculated on different media (MS, $1 / 2 \mathrm{MS}$ and wateragar) for in vitro germination. Nodal segments of in vitro germinated jambu seedlings were used as explants in the micropropagation with different concentrations of 6-benzylaminopurine (BAP) (0.0; $0.125 ; 0.25 ; 0.50$ and $\left.0.75 \mathrm{mg} \mathrm{L}^{-1}\right)$ and callus induction with $2.4-$ dichlorophenoxyacetic acid (2.4-D) $(0.0 ; 0.25 ; 0.50 ; 0.75$ and $1.0 \mathrm{mg}$ $\mathrm{L}^{-1}$ ) on Murashige \& Skoog's (MS) medium. The highest germination rates were obtained on MS medium with better seedling development and greater height $(3.7 \mathrm{~cm})$. In micropropagation, the best treatment was obtained on 0.125 BAP (T2), with an average of 2.2 sprouts/ explant, average height of $2.4 \mathrm{~cm}$ and vigorous sprouts. In callus induction, all treatments with 2.4-D had developed friable calluses in 30 days and using doses of 0.25 and $0.50 \mathrm{mg} \mathrm{L}^{-1}$ provided greater fresh matter. The induction of friable callus and the root production occur without supplementation of exogenous growth regulator.
\end{abstract}

Keywords: Acmella oleracea, micropropagation, callus induction, BAP, 2.4-D, nodal segments.

\section{RESUMO}

Cultivo in vitro de jambu com diferentes reguladores de crescimento

Objetivou-se estabelecer as melhores concentrações de reguladores de crescimento para o cultivo in vitro de jambu, visando a posterior elaboração de um protocolo eficiente de micropropagação. Após assepsia, sementes foram inoculadas em meios diversos (MS, 1/2MS e água-ágar) para germinação in vitro. Segmentos nodais de plântulas germinadas in vitro foram utilizados como explante na micropropagação com diferentes concentrações de 6-benzilaminopurina (BAP) $\left(0,0 ; 0,125 ; 0,25 ; 0,50\right.$ e $\left.0,75 \mathrm{mg} \mathrm{L}^{-1}\right)$ e na indução de calos com ácido 2,4-diclorofenoxiacético (2,4-D) $\left(0,0 ; 0,25 ; 0,50 ; 0,75\right.$ e $\left.1,0 \mathrm{mg} \mathrm{L}^{-1}\right)$ em meio MS. Maiores taxas de germinação foram obtidas em meio MS, com melhor desenvolvimento das plântulas e maior altura $(3,7 \mathrm{~cm})$. Na micropropagação o melhor tratamento foi em $0,125 \mathrm{mg} \mathrm{L}^{-1}$ BAP (T2), com média de 2,2 brotações/explante e altura média de $2,4 \mathrm{~cm}$ e brotações vigorosas. $\mathrm{Na}$ indução de calos todos os tratamentos com 2,4-D formaram calos friáveis em 30 dias e as doses de 0,25 e $0,50 \mathrm{mg} \mathrm{L}^{-1}$ de 2,4-D proporcionaram maior massa da matéria fresca. A indução de calos friáveis e a produção de raízes ocorrem sem a suplementação de regulador de crescimento exógeno.

Palavras-chave: Acmella oleracea, micropropagação, indução de calos, BAP, 2,4-D, segmento nodal.

\section{Received on April 3, 2019; accepted on March 27, 2020}

$A^{c}$ cmella oleracea (Spilanthes acmella), popularly known in Brazil as "jambu" and in India as "toothache plant", is an important medicinal herb belonging to Asteraceae family being a non-conventional vegetable found in tropical and subtropical regions. It is originated from the Brazilian tropics, widely grown as ornamental and medicinal plant in various parts of the world (Nabi \& Shrivastava, 2015) and used as spice in the Northern part of the country (Favoreto \& Gilbert, 2010; Gusmão \& Gusmão, 2013; Prushothaman et al., 2018).
Jambu has attracted the interest among researchers and of national and multinational companies, due to the properties of its extract which presents antioxidants, analgesics, antibacterial, diuretics and anti-inflammatory functions; it also has ovicidal and larvicidal activities against Aedes aegypti and Anopheles culicifacies mosquitoes. Several of these properties are due to the presence of spilantol alcamide, with numerous applications in pharmaceutical industries (Cheng et al., 2015; Barbosa et al., 2016; Dallazen et al., 2019). This species is also promising in cosmetics area, since some studies have been proving that spilantol has shown potential anti-skin effect, relaxing the microtensions, acting as "anti-wrinkles" (Demarne \& Passaro, 2009).

Although jambu is conventionally propagated by seeds and cuttings (Gusmão \& Gusmão, 2013), micropropagation is a technique of great importance for large-scale multiplication of the species and an alternative which can prevent genetic erosion caused by indiscriminate collection and frequent deforestation in areas of natural 
occurrence of the species. Moreover, in vitro plant cell and tissue culture can standardize and even increase synthesis of bioactive substances in plants (Wang et al., 2017).

Thus, considering the economic and medicinal importance of this plant (Acmella oleracea), the aim of this study was to establish the best concentrations of phytoregulators for in vitro cultivation of the species, aiming a subsequent elaboration of an efficient micropropagation protocol.

\section{MATERIAL AND METHODS}

The experiment was carried out in Laboratório de Biotecnologia Vegetal do LABISISBIO (Laboratories of Systematic Researches in Biotechnology and Molecular Biodiversity) at Universidade Federal do Pará (UFPA).

\section{In vitro germination}

Jambu seeds obtained from hydroponic cultivation in a laminar flow cabinet were immersed in $70 \%$ alcohol $(\mathrm{v} / \mathrm{v})$ for 1 minute, then in sodium hypochlorite $(\mathrm{NaClO})(\mathrm{v} / \mathrm{v})$ containing $2.0 \%$ active chlorine, for 20 minutes. Afterwards, the seeds were washed three times in sterile distilled water. After asepsis, the seeds were inoculated in bottles containing $30 \mathrm{~mL}$ of different media in order to evaluate germination $[\mathrm{T} 1=\mathrm{MS}$ medium (Murashige \& Skoog, 1962), T2= medium containing half concentration of macro- and micronutrient salts of MS ( $1 / 2$ MS) and T3= water-agar medium]. All the media used in the experiments were supplemented with $30 \mathrm{~g} \mathrm{~L}^{-1}$ sucrose and solidified with $8 \mathrm{~g} \mathrm{~L}^{-1}$ agar. The medium $\mathrm{pH}$ was adjusted to 5.8 and the bottles were autoclaved for 15 minutes at $121^{\circ} \mathrm{C}$ (1.0 atm pressure). The inoculated seeds were kept in a BOD incubator at $25 \pm 2{ }^{\circ} \mathrm{C}, 16 \mathrm{~h}$ light photoperiod and $25 \mu \mathrm{mol} \mathrm{m} \mathrm{m}^{-2} \mathrm{~s}^{-1}$ luminous intensity for 30 days. A completely randomized design, with three treatments, was used. Each treatment consisted of 25 seeds, five replicates. Observations were made every seven days for 30 days. Germination percentage variables, height $(\mathrm{cm})$ and quality of seedlings obtained were evaluated by Scott-Knott test, at 5\% probability using RStudio software.

\section{Micropropagation}

Nodal segments of in vitro germinated jambu seedlings were inoculated on basic MS medium supplemented with $30 \mathrm{~g} \mathrm{~L}^{-1}$ sucrose and solidified with $8 \mathrm{~g}$ $\mathrm{L}^{-1}$ agar and supplemented with different concentrations of BAP $\left(\mathrm{T} 1=0.0 \mathrm{mg} \mathrm{L}^{-1}\right.$; $\mathrm{T} 2=0.125 \mathrm{mg} \mathrm{L}^{-1}$; $\mathrm{T} 3=0.25 \mathrm{mg} \mathrm{L}^{-1} ; \mathrm{T} 4=$ $0.5 \mathrm{mg} \mathrm{L}^{-1}$; T5 $\left.=0.75 \mathrm{mg} \mathrm{L}^{-1}\right)$. Explants were inoculated on the media and kept in a BOD incubator at $25 \pm 2^{\circ} \mathrm{C}, 16$ $\mathrm{h}$ light photoperiod and $25 \mu \mathrm{mol} \mathrm{m} \mathrm{m}^{-2}$ $\mathrm{s}^{-1}$ luminous intensity for 25 days. A completely randomized design with five treatments was used, which consisted of six explants for each treatment, three replicates. Each replicate consisted of one bottle with two nodal segments. Observations were made every seven days for 25 days and the number of shoots and height $(\mathrm{cm})$ were evaluated by Scott-Knott test, at 5\% probability using RStudio software.

\section{Callus induction}

Nodal segments were inoculated on basic MS medium supplemented with $30 \mathrm{~g} \mathrm{~L}^{-1}$ sucrose and solidified with $8 \mathrm{~g} \mathrm{~L}^{-1}$ agar and supplemented with different concentrations of auxin 2.4-dichlorophenoxyacetic acid (2.4-D) $\left(\mathrm{T} 1=0.0 \mathrm{mg} \mathrm{L}^{-1} ; \mathrm{T} 2=0.25 \mathrm{mg} \mathrm{L}^{-1} ; \mathrm{T} 3=\right.$ $0.5 \mathrm{mg} \mathrm{L}^{-1} ; \mathrm{T} 4=0.75 \mathrm{mg} \mathrm{L}^{-1} ; \mathrm{T} 5=1.0$ $\mathrm{mg} \mathrm{L}^{-1}$ ). After inoculation, the explants were kept in an incubator at $25 \pm 2^{\circ} \mathrm{C}$, $16 \mathrm{~h}$ light photoperiod for 25 days. A completely randomized design with five treatments and three replicates was used, which consisted of six explants for each treatment, two explants per replicate. We compared average fresh mass (mg) by Scott-Knott test, at 5\% probability using RStudio software. Friability and callus induction percentage were also evaluated.

\section{RESULTS AND DISCUSSION}

\section{In vitro germination}

In vitro germination of jambu began from the second day of inoculation and on the fourth day, $64 \%$ of the seeds of T1 (MS medium) were already germinated, showing that in vitro germination process is pretty fast. According to Gusmão \& Gusmão (2013), the average germination of jambu in nurseries is $90 \%$ and occurs only from the fourth day after sowing in the field at temperatures from $25^{\circ} \mathrm{C}$ to $33^{\circ} \mathrm{C}$. Environmental factors such as temperature, water and light availability considerably influence germination process, considering that the quantity of these factors ranges according to the species. Moreover, factors like medium chemical composition and hormonal balance also strongly influence germination process (Carvalho \& Nakagawa, 2012). Thus, controlled conditions in in vitro germination favored the acceleration of germination.

We noticed a difference in in vitro germination of jambu using different culture media (Table 1). MS medium stood out among the others; this treatment showed the highest germination (88\%), with the highest average of germinated seeds (4.4). Whereas the medium containing half concentrations of macro and micronutrient salts of MS ( $1 / 2 \mathrm{MS})$ showed the lowest germination (64\%) and average of germinated seeds $(3.2 \%)$. This result did not differ statically from treatment T3, using water-agar medium, showing $48 \%$ in vitro germination and 2.4 average of germinated seeds.

The highest percentage of in vitro germination of jambu, using MS medium can be explained by the fact that this medium is quite rich in macronutrients, micronutrients and vitamins (Dezan et al., 2012); however, nutritional demands are very specific, widely varying among different species.

In relation to in vitro seedling development, the least efficient treatment was the one using the wateragar medium, showing undeveloped seedlings measuring $0.28 \mathrm{~cm}$-high, since the germinated seedlings did not find nutrients for its development in this medium. MS and $1 / 2 \mathrm{MS}$ media showed the best result with seedlings presenting good development and vigor, $3.7 \mathrm{~cm}$ and $3.96 \mathrm{~cm}$ respectively, showing that a medium with nutrients is more conducive to the development of jambu seedlings.

In germination, initially, seeds need good aeration and availability of water to germinate, since they use nutrients from their own resources. However, 
when their resources are used up, the germinated seedlings will need nutrients to develop properly (Vidal \& Vidal, 2000).

Cultivation conditions, mainly the culture medium used in the experiment, are essential in this first moment of in vitro establishment, since the appropriate combination of the components is decisive for the success of germination and obtaining a greater number of seedlings. So, the MS medium showed higher germination percentage, probably due to the presence of higher quantity of macro- and micronutrients and vitamins, appropriate substances which make the seed develop efficiently after germination under in vitro conditions. Silva \& Ferreira (2016) assert that the nutrients used for cultures provide the essential substances for tissue development and control the growth and pattern of in vitro development by the presence of hormones or growth regulators.

\section{Micropropagation}

Table 1. Percentage of germination and average of in vitro germination, seedling height and contamination (\%) of Acmella oleracea after 30 days treatment in different culture media. UFRA, Belém, 2019.

\begin{tabular}{lcccc}
\hline Treatments & $\begin{array}{c}\text { Germination } \\
(\%)\end{array}$ & $\begin{array}{c}\text { Average } \\
\text { germination }\end{array}$ & $\begin{array}{c}\text { Seedling } \\
\text { height }(\mathbf{c m})\end{array}$ & $\begin{array}{c}\text { Contamination } \\
(\mathbf{\%})\end{array}$ \\
\hline MS medium & $88 \mathrm{a}$ & $4.4 \mathrm{a}$ & $3.70 \mathrm{a}$ & 0 \\
1/2MS medium & $64 \mathrm{~b}$ & $3.2 \mathrm{~b}$ & $3.96 \mathrm{a}$ & 0 \\
Water-agar medium & $48 \mathrm{~b}$ & $2.4 \mathrm{~b}$ & $0.28 \mathrm{~b}$ & 20 \\
\hline
\end{tabular}

*Average values followed by same lowercase letters in a column do not differ, Scott-Knott test.

Table 2. Number of shoots, shoot height and seedling morphology of Acmella oleracea seedlings on MS micropropagation medium with different BAP concentrations after 30 days. UFRA, Belém, 2019.

\begin{tabular}{|c|c|c|c|}
\hline $\begin{array}{l}\text { BAP concentrations } \\
\left(\mathrm{mg} \mathrm{L}^{-1}\right)\end{array}$ & $\mathbf{N}^{0}$ of shoots & Height (cm) & Morphology \\
\hline 0.0 & $1.4 \mathrm{a}$ & $7.0 \mathrm{a}$ & Many roots \\
\hline 0.125 & $2.2 \mathrm{a}$ & $2.4 \mathrm{~b}$ & $\begin{array}{l}\text { Shoots showing good } \\
\text { development and vigor }\end{array}$ \\
\hline 0.25 & $3.0 \mathrm{a}$ & $1.8 \mathrm{~b}$ & $\begin{array}{l}\text { callus at the base and } \\
\text { glazed appearance }\end{array}$ \\
\hline 0.5 & $2.5 \mathrm{a}$ & $0.66 \mathrm{c}$ & $\begin{array}{l}\text { callus at the base and } \\
\text { glazed appearance }\end{array}$ \\
\hline 0.75 & $2.0 \mathrm{a}$ & $2.5 b$ & $\begin{array}{l}\text { callus at the base and } \\
\text { glazed appearance }\end{array}$ \\
\hline
\end{tabular}

*Average values followed by same lowercase letters in a column do not differ, Scott-Knott test.
In the culture medium, a high concentration of cytokinin in relation to auxin promotes the proliferation of shoots and suppresses root development, whereas a low concentration of cytokinins in relation to a higher concentration of auxins in the medium favors root development. According to Grattapaglia \& Machado (1998), excessive concentrations of auxins can inhibit multiplication and favor rooting or callus formation. Therefore, it can be inferred that the treatment (in this study) with $A$. oleracea must have a low concentration of cytokinin and a high endogenous amount of auxin in plant, due to the proliferation of a large quantity of roots observed.

We noticed no differences in number of shoots in any of the treatments proposed (Table 2). The treatment with $0.25 \mathrm{mg} \mathrm{L}^{-1}$ BAP presented callus at the base, glazed appearance and low growth, characteristics which does not favor micropropagation.

Using $0.125 \mathrm{mg} \mathrm{L}^{-1} \mathrm{BAP}$, despite no differences between the other BAP concentrations in relation to the number of shoots per explant (2.2) had been noticed, this was the only treatment which presented more vigorous shoots and well developed leaves, without callus and vitrification, in addition to having good growth $(2.4 \mathrm{~cm})$ compared to treatment $0.25 \mathrm{mg} \mathrm{L}^{-1} \mathrm{BAP}$ (Table 2).

Roman et al. (2016) stated that shoot growth is controlled by environmental and endogenous factors and that light acts mainly as a morphogenic signal in triggering shoot proliferation via cytokinins.

Crispim et al. (2014), evaluating different concentrations of BAP in sugar cane observed that the medium supplemented with BAP, at doses 0.5 or $1.0 \mathrm{mg} \mathrm{L}^{-1}$, provided better shoot development and greater gain of fresh mass than in the medium without addition of phytoregulators.

High contents of exogenous hormonal supply can interfere with morphogenesis and form undifferentiated and disorganized cell masses, called callus, which are undesirable when we sought to develop a micropropagation procedure, which occurred using 0.25 , 0.50 and $0.75 \mathrm{mg} \mathrm{L}^{-1}$ BAP (Figure 1). 
Table 3. Average callus induction (\%), fresh mass and callus morphology of Acmella oleracea after 30 days on MS medium with different 2.4-D concentrations. UFRA, Belém, 2019.

\begin{tabular}{|c|c|c|c|}
\hline $\begin{array}{l}\text { Concentrations } \\
\text { of 2.4-D }\left(\mathrm{mg} \mathrm{L}^{-1}\right)\end{array}$ & $\begin{array}{c}\text { Induction } \\
(\%)\end{array}$ & $\begin{array}{c}\text { Fresh } \\
\text { mass (mg) }\end{array}$ & Morphology \\
\hline 0.0 & 0 & $0.0 \mathrm{~b}$ & $\begin{array}{l}\text { Many adventitious roots, } \\
\text { without callus development }\end{array}$ \\
\hline 0.25 & 100 & $0.4 \mathrm{a}$ & $\begin{array}{l}\text { Friable callus, beige color, } \\
\text { small root }\end{array}$ \\
\hline 0.50 & 100 & $0.3 \mathrm{a}$ & $\begin{array}{l}\text { Friable callus, beige color, } \\
\text { small root and leaves }\end{array}$ \\
\hline 0.75 & 100 & $0.1 b$ & $\begin{array}{l}\text { Friable callus, beige color, } \\
\text { small leaves }\end{array}$ \\
\hline 1.0 & 100 & $0.2 \mathrm{~b}$ & $\begin{array}{l}\text { Friable callus, dark brown } \\
\text { color }\end{array}$ \\
\hline
\end{tabular}

*Average values followed by same lowercase letters in a column do not differ, Scott-Knott test.

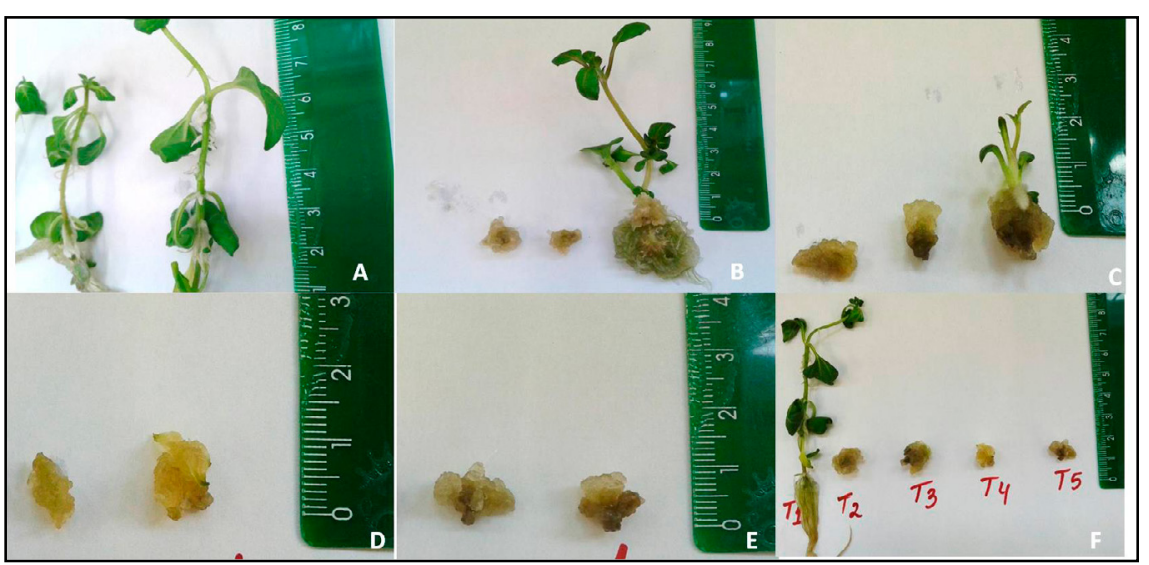

Figure 1. Callus induction of Acmella oleracea after 30 days at different concentrations of 2.4-D. A (T1) $=0.0 \mathrm{mg} \mathrm{L}^{-1}$; B (T2) $=0.25 \mathrm{mg} \mathrm{L}^{-1} ; \mathrm{C}(\mathrm{T} 3)=0.50 \mathrm{mg} \mathrm{L}^{-1} ; \mathrm{D}(\mathrm{T} 4)=0.75 \mathrm{mg} \mathrm{L}^{-1}$; $\mathrm{E}(\mathrm{T} 5)=1.0 \mathrm{mg} \mathrm{L}^{-1} ; \mathrm{F}=$ all treatments of callus induction. UFRA, Belém, 2019.

Besides formation of calluses, these treatments also showed seedlings with abnormal development, reduction in size and vitrification.

According to Vasconcelos et al. (2012), hyperhydricity, formerly called vitrification, is considered a physiological, biochemical and morphological disorder resulting from the abnormal accumulation of water inside cells and tissues. This disorder can be triggered by physical factors, related to the environment of the culture vessels and consistency of the culture medium or by chemical factors such as the components of the culture medium, especially growth regulators in high concentrations.

Gao et al. (2018) analyzing physiological and structural alterations in hyperhydric blueberry seedlings
In the absence of 2.4-D, containing MS medium without regulator, it was the only one which did not induce calluses, due to its non-supplementation with the hormone auxin 2.4-D. However, at the end of 30 days, it showed a large amount of adventitious roots in its plant material, confirming that the explants used in jambu had shown endogenous hormones in their constitution.

Auxins act in growth and control of cell differentiation, regulating the activity of protein kinases dependent on cyclin type A (CDK/a) together with the cytokinins which activate D3 cyclins (CYC/D3). When active complex $\mathrm{CDK} / \mathrm{a}-\mathrm{CYC} / \mathrm{D}_{3}$ is formed, cells acquire the ability to enter the cell cycle (Mercier, 2012).

Using $0.25 \mathrm{mg} \mathrm{L}^{-1}$ of $2.4-\mathrm{D}$, the authors observed that even in low concentrations, 2.4-D favors the development of friable calluses, beige in color, with small roots (Table 3). This reinforces Grattapaglia \& Machado's (1998) statement that 2.4-dichlorophenoxyacetic acid (2.4D) tends to stimulate callus formation, even at low concentrations.

Treatments 0.25 and $0.5 \mathrm{mg} \mathrm{L}^{-1} 2.4-$ $D$ presented the best results, in addition to reaching $100 \%$ callus induction, they had a greater amount of fresh mass $(0.4$ $\mathrm{mg}$ and $0.3 \mathrm{mg}$, respectively) without differing among each other. These treatments also demonstrated calluses with a tendency for organogenesis, as they exhibited the formation of roots and leaves in their structures.

Treatments 0.75 and $1 \mathrm{mg} \mathrm{L}^{-1}$ 2.4-D induced $100 \%$ callus formation, with 0.1 and $0.2 \mathrm{mg}$ fresh mass, respectively, neither differing from each other, nor among the treatments without regulator.

Callus induction requires explant selection, proper supply of nutrients in the environment and appropriate environmental conditions. Phua et al (2016) obtained callus from the medicinal plant Clinacanthus nutans with a higher average of callus fresh mass using explants of young leaves from MS medium supplemented with $0.5 \mathrm{mg} / \mathrm{L}$ 2.4-D. Soorni \& Kahrizi (2015) showed that using MS medium supplemented with 2.4-D, the genotype and type of explant interfere with both 
callus induction and growth in Cuminum cyminum accessions.

Thus, MS medium was the most efficient for jambu seed germination. Even without any supplementation of phytohormone BAP or 2.4$\mathrm{D}$, the species $A$. oleracea induced the formation of shoots and roots, showing the presence of high levels of endogenous hormones. Nodal segments of jambu in MS medium supplemented with $0.125 \mathrm{mg} \mathrm{L}^{-1}$ BAP showed higher shoot quality. BAP contents higher than $0.25 \mathrm{mg} \mathrm{L}^{-1}$ formed calluses and leaves with abnormal development and vitrification. MS medium supplemented with concentrations ranging from 0.25 to $1.0 \mathrm{mg} \mathrm{L}^{-1} 2.4-\mathrm{D}$ favored the development of friable calluses in nodal segments of jambu and doses of 0.25 and $0.50 \mathrm{mg} \mathrm{L}^{-1} 2.4-\mathrm{D}$ provided greater fresh mass. Some studies have been carried out in order to verify the influence of other growth regulators and other concentrations to obtain an efficient protocol for an in vitro cultivation of this species.

\section{ACKNOWLEDGEMENTS}

The authors thank to Labisisbio (UFPA) for the partnership in this study.

\section{REFERENCES}

ALGABRI, AA; PANDHURE, N. 2019. In vitro micropropagation studies in Spilanthes acmella Murr. International Journal of Scientific Research 8: 53-54.

BARBOSA, AF; CARVALHO, MG; SMITH, RE; ARMANDO, UOSS. 2016. Spilanthol: occurrence, extraction, chemistry and biological activities. Revista Brasileira de Farmacognosia 26: 128-133.
CARVALHO, NM; NAKAGAWA, J. 2012. Sementes: ciência, tecnologia e produção. 5.ed. FUNEP: Jaboticabal, 590p.

CHENG, Y; LIU, RH; HO, M; WU, T; CHEN, C; LO, I; HOU, M; YUAN, S; WU, Y; CHANG, F. 2015. Alkylamides of Acmella oleracea Molecules 20: 6970-6977.

CRISPIM, JG; RÊGO, MM; RÊGO, ER; MEDEIROS, GDA; SOARES, WS; PESSOA, MAS. 2014. Efeito da benzilaminopurina e da cinetina sobre potencial morfogênico de canade-açúcar. Revista Agrotec 35: 94-99.

DALLAZEN, JL; FERREIRA, DM; LUZ, BB; NASCIMENTO, AM; CIPRIANI, TR; SOUZA, LM; FELIPE, LPG; SILVA, BJG; NASSINI, R; WERNER, MFP. 2019. Pharmacological potential of alkylamides from Acmella oleracea flowers and synthetic isobutylalkyl amide to treat inflammatory pain. Inflammopharmacology. Available https://doi.org/10.1007/s10787-019-00601-9

DEMARNE, F; PASSARO, G. 2009. Use of an Acmella oleracea extract for the botulinum toxin-like effect thereof in an antiwrinkle cosmetic composition. US Patent No. 7,531,193 B2.

DEZAN, LF; CANASSA, F; SOUZA-LEAL, T; DIOGO, JA; MASSARO, R; CORDEIRO, GM; PEDROSO DE MORAES, C. 2012. Crescimento in vitro de Schomburgkia gloriosa Lindl. em meio de cultivos simplificados. Idesia 30: 53-38.

FAVORETO, R; GILBERT, B. 2010. Acmella oleracea (L.) R. K. Jansen (Asteraceae) Jambu. Revista Fitos 5: 83-91.

GAO, H; LI, J; JI, H; NA, L; XIA, X. 2018. Hyperhydricity-induced ultrastructural and physiological changes in blueberry (Vaccinium spp.). Plant Cell, Tissue and Organ Culture 133: $65-76$

GRATTAPAGLIA, D; MACHADO, MA. 1998. Micropropagação. In: TORRES, AC; CALDAS, LS; BUSO, JÁ (eds). Cultura de tecidos e transformação genética de plantas. Brasília: Embrapa. v.1, p.183-260.

GUSMÃO, MTA; GUSMÃO, SAL. 2013. Jambu da Amazônia Acmella oleracea [(L.) R. K. Jansen] - Características gerais, cultivo convencional, orgânico e hidropônico. Belém: UFRA, 135p.

MERCIER, H. 2012. Auxinas. In: KERBAUY, GB (ed). Fisiologia Vegetal. Rio de Janeiro: Guanabara Koogan, p. 431-436.

MURASHIGE, T; SKOOG, F. 1962. A revised medium for rapid growth and bioassays with tobacco tissue culture. Physiology Plantarum 15: 473-497.

NABI, NG; SHRIVASTAVA, M. 2015. Spilanthes acmella Murr. an important endangered medicinal plant and its conservation through tissue culture techniques. Indian Journal of Applied And Pure Biology 30: 159-163.

NABI, NG; SHRIVASTAVA, M; KHAN, AA; RASHID, A; DAR, SH. 2018. Organogenesis in callus derived from leaf explants of Spilanthes acmella Linn: An endangered medicinal plant. Journal of Pharmacognosy and Phytochemistry 7: 01-07.

PHUA, QY; CHIN, CK; ASRI, ZRM; LAM, DYA; SUBRAMANIAM, S; CHEW, BL. 2016. The callugenic effects of 2,4-dichlorophenoxy acetic acid (2,4-D) on leaf explants of Sabah snake grass (Clinacanthus nutans). Pakistan Journal of Botany 48: 561-566.

PRUSHOTHAMAN, Y; GUNASEELAN, S; VIJAYAKUMAR, SD. 2018. Spilanthes acmella and its medicinal uses - a review. Asian Journal of Pharmaceutical and Clinical Research 11: 45-49.

ROMAN, H; GIRAULT, T; BARBIER, F; PÉRON, T; BROUARD, N; PĚNČÍK, A; NOVÁK, O; VIAN, A; SAKR, S; LOTHIER, J; GOURRIEREC, JL; LEDUC, N. 2016. Cytokinins are initial targets of light in the control of bud outgrowth. Plant Physiology 172: 489-509.

SILVA, MMA; FERREIRA, LT. 2016. Cultivo in vitro e suas aplicações em cactáceas. Campina Grande: INSA, 32p.

SOORNI, J; KAHRIZI, D. 2015. Effect of genotype, explant type and 2,4-D on cell dedifferentiation and callus induction in cumin (Cuminum cyminum L.) medicinal plant. Journal of Applied Biotechnology Reports 2: 187-192.

VASCONCELOS, AGV; TOMAS, LF; CAMARA, TR; WILLADINO, L. 2012. Hiperhidricidade: uma desordem metabólica. Ciência Rural 42: 837-844.

VIDAL, WN; VIDAL, MRR. 2000. Botânicaorganografia. $4^{a}$ ed. Versão ampliada. Viçosa: UFV. p.67-76 il.

WANG, J; LI, J; LI, J; LI, J; LIU, S; HUANG, L; GAO, W. 2017. Production of active compounds in medicinal plants: from plant tissue culture to biosynthesis. Chinese Herbal Medicines 9: 115-125. 